\title{
Community structures of cold and low-nutrient adapted heterotrophic sediment bacteria from the deep eastern tropical Atlantic*
}

\author{
Hans-Jürgen Rüger, Tjhing Lok Tan
}

Alfred-Wegener-Institut für Polar- und Meeresforschung, W-2850 Bremerhaven, Germany

\begin{abstract}
Colony counts on high and low-nutrient agar media incubated at 2 and $20^{\circ} \mathrm{C}$. Acridine Orange Direct Counts and biomasses are reported for sediments of the Sierra Leone Abyssal Plain. All isolates from low-nutrient agars also grew in nutrient-rich seawater broth (100\% SWB). However, a greater proportion of the $2{ }^{\circ} \mathrm{C}$ than of the $20^{\circ} \mathrm{C}$ isolates grew in $2.5 \% \mathrm{SWB}$, containing $125 \mathrm{mg} \mathrm{l^{-1 }}$ peptone and $25 \mathrm{mg} \mathrm{l}^{-1}$ yeast extract. Only 14 strains or $12.7 \%$ of the $2^{\circ} \mathrm{C}$ isolates, but none of the $20^{\circ} \mathrm{C}$ isolates, grew in $0.25 \% \mathrm{SWB}$. Psychrophilic bacteria with maximum growth temperatures below $12^{\circ} \mathrm{C}$, isolated at $2{ }^{\circ} \mathrm{C}$, were predominant among the cultivable bacteria from the surface layer. They required seawater for growth and belonged mainly to the Gram-negative genera Alteromonas and Vibrio. In contrast to the earlier view that psychrophily is connected with the Gram-negative cell type, it was found that cold-adapted bacteria of the Gram-positive genus Bacillus predominated in the 4 to $6 \mathrm{~cm}$ layer The $20^{\circ} \mathrm{C}$ isolates, however, were mostly Gram-positive, mesophilic, not dependent on seawater for growth, not able to utilize organic substrates at $4^{\circ} \mathrm{C}$, and belonged mainly to the genus Bacillus and to the Gram-positive cocci. The majority of the mesophilic bacilli most likely evolved from dormant spores, but not from actively metabolizing cells. It can be concluded that only the strains isolated at $2{ }^{\circ} \mathrm{C}$ can be regarded as indigenous to the deep-sea.
\end{abstract}

\section{INTRODUCTION}

High hydrostatic pressure, low temperature and, especially in abyssal plains, low concentrations of organic substrates characterize deep-sea environments. Although the effects of pressure and temperature cannot be considered independently (Deming 1986. Yayanos 1986), the low temperature may be more important in this extreme environment for bacterial communities (Jaenicke 1988). Except for a few obligate barophiles (Deming 1986, Yayanos 1986, Deming et al. 1988, Chastain \& Yayanos 1991), most deep-sea isolates studied so far were able to survive decompression and to grow at atmospheric pressure (Jannasch \& Wirsen 1984).

Although deep-sea temperatures are generally below about $3{ }^{\circ} \mathrm{C}$, studies on the size and structure of cultivable

\footnotetext{
- Contribution No. 535 of the Alfred-Wegener-Institut für Polar- und Meeresforschung, Bremerhaven
}

psychrophilic bacterial communities from marine sediments have been reported only from polar and subpolar regions (Norkrans \& Stehn 1978, Kaneko et al. 1979, Hauxhurst et al. 1980, Tanner \& Herbert 1982). From other marine regions, e.g. tropical or subtropical, psychrophilic or psychrotrophic bacteria sensu Morita (1975) have been isolated only occasionally from deep-sea samples (Baross \& Morita 1978, Tabor et al. 1982, Deming 1986). Extreme psychrophiles which failed to grow at temperatures above $10^{\circ} \mathrm{C}$ are known from the deep Norwegian Sea (Norkrans \& Stehn 1978), from Antarctic waters (Baross \& Morita 1978) and from bottom sediments of the northwest African upwelling area (Rüger 1984). Yayanos \& Dietz (1982) reported the inactivation of a barophilic deep-sea bacterium from the central North Pacific ocean after exposures to temperatures between 10 and $32{ }^{\circ} \mathrm{C}$ and at different hydrostatic pressures. Thus, incubation temperatures between 15 and $20^{\circ} \mathrm{C}$ or even higher, still used for the isolation of deep-sea bacteria (Tabor et al. 1981, Bensoussan et al. 1984, Namsaraev 
1985), must inhibit the growth of autochthonous bacteria having lower maximum growth temperatures.

Besides $20^{\circ} \mathrm{C}$, i.e the maximum growth temperature for psychrophiles according to the generally adopted definition given by Morita (1975), an additional incubation temperature of $2{ }^{\circ} \mathrm{C}$ was therefore applied for the enumeration and isolation of sediment bacteria from the northwest African upwelling area. Incubated at $2{ }^{\circ} \mathrm{C}$, the numbers of colony forming units from $1500 \mathrm{~m}$ depth were almost 1 order of magnitude higher than at $20^{\circ} \mathrm{C}$. indicating a predominance of psychrophilic bacteria in the greater depths of this subtropic region (Rüger 1982). The percentage of psychrophilic or even extremely psychrophilic strains among the $2^{\circ} \mathrm{C}$ isolates increased with increasing depths; all strains were Gram-negative and most of them belonged to the genera Alteromonas and Vibrio (Rüger 1989).

The same incubation temperatures of 2 and $20^{\circ} \mathrm{C}$ were used for community structure studies of bacteria in sediments of the Sierra Leone Abyssal Plain and the slope of the Sierra Leone Rise. In the topmost $2 \mathrm{~cm}$ of the sediments, the majority of the isolates from $2{ }^{\circ} \mathrm{C}$ cultures worc Gram-nogative and psychrophilic or even extremely psychrophilic with maximum growth temperatures between 4 and $12{ }^{\circ} \mathrm{C}$. In contrast the isolates from $20^{\circ} \mathrm{C}$ cultures belonged almost entirely to the Gram-positive cell type (Rüger 1986). To evaluate which group of bacteria can be regarded as indigenous to the deep-sea environment, in this study we compared the community structures of the $2^{\circ} \mathrm{C}$ isolates from the sediment surface and from a deeper 4 to $6 \mathrm{~cm}$ layer with those of the $20^{\circ} \mathrm{C}$ isolates.

Although organic material can be transported through the water column by sedimentation events, the main components reaching the deep-sea floor are refractory. Abyssal seawaters and sediments are thus oligotrophic habitats (Carlucci et al. 1986, Deming 1986, Fry 1990) and deep-sea bacteria should therefore be adapted to lownutrient concentrations. To examine this, the abilities of the strains to grow in low-nutrient media were tested and the isolation of oligotrophic bacteria by employment of enrichment cultures was also attempted.

\section{MATERIALS AND METHODS}

Sampling methods and station locations. During the cruise GEOTROPEX ' 83 with RV 'Meteor' in August 1983 (Fig, 1), sediment samples were taken from various depths
(Table 1) in the eastern Atlantic Ocean between 3 and $17^{\circ} \mathrm{N}$ by means of a box-grab sampler (surface area $50 \times 50 \mathrm{~cm}$ ). After careful siphoning to remove the overlying seawater, subsamples were drawn with a sterile $15 \times 2 \mathrm{~cm}$ corer, about $10 \mathrm{~cm}$ deep, from near the centre of the sediment surface in order to take unwarmed samples. Sediment temperatures (Table 1) were measured with an electronic thermometer. The subsample cores were sectioned into layers $2 \mathrm{~cm}$ deep, and sediments from the 0 to 2 and 4 to $6 \mathrm{~cm}$ layers were each collected in sterile $100 \mathrm{ml}$ flasks. Sediments in the flasks were thoroughly mixed with a spatula and kept in a refrigerator until further processing on board

Colony counts and isolation of strains. Viable count determinations were carried out with the spread plate method on high-nutrient and lownutrient seawater agars after appropriate dilution of the samples in sterile $75 \%$ seawater. The agar plates and all solutions were chilled to $4^{\circ} \mathrm{C}$ on a cold tray during the whole inoculation procedure. The plates were prepared in triplicate and incubated on board at 2 and $20^{\circ} \mathrm{C}$, respectively. Counting and random iso-

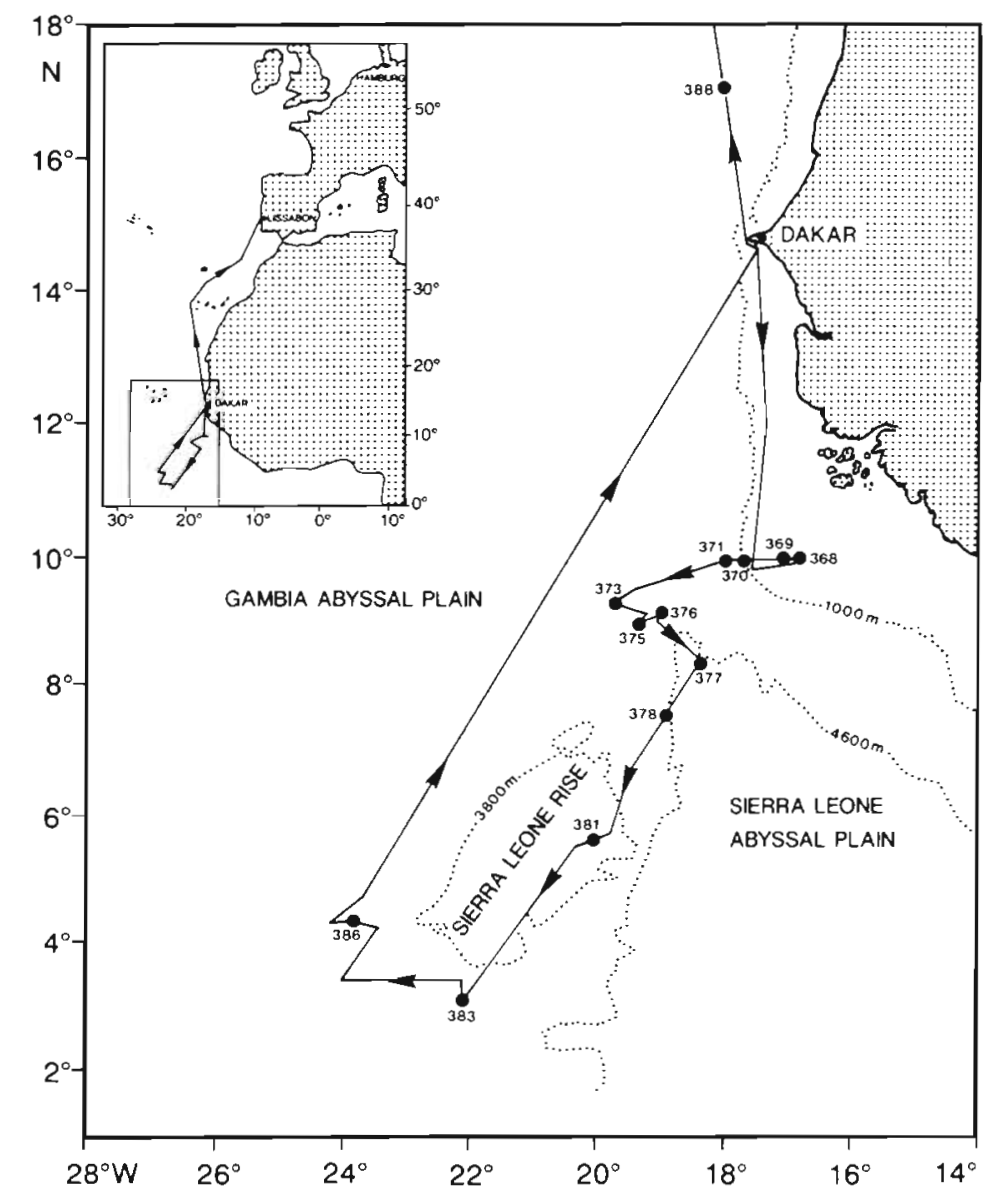

Fig. 1. Station locations in the eastern tropical Atlantic during the cruise GEOTROPEX ' 83 with RV 'Meteor' 
Table 1. Position of sampling stations, grouped according to latitude, bacterial numbers from agar cultures at 2 or $20^{\circ} \mathrm{C}$ incubation temperatures and Acridine Orange Direct Counts (AODC), and biomasses per ml of wet sediment. nd: not determined

\begin{tabular}{|c|c|c|c|c|c|c|c|c|c|c|}
\hline \multirow[t]{2}{*}{ Stn } & \multirow{2}{*}{$\begin{array}{l}\text { Latitude } \\
\qquad(\mathrm{N})\end{array}$} & \multirow{2}{*}{$\begin{array}{c}\text { Depth } \\
\text { (m) }\end{array}$} & \multirow{2}{*}{$\begin{array}{l}\text { Sediment } \\
\text { temp. } \\
\left({ }^{\circ} \mathrm{C}\right)\end{array}$} & \multirow{2}{*}{$\begin{array}{c}\text { Sediment } \\
\text { layer } \\
(\mathrm{cm})\end{array}$} & \multicolumn{4}{|c|}{ Colony counts } & \multirow{2}{*}{$\begin{array}{l}\text { AODC } \\
\times 10^{7}\end{array}$} & \multirow{2}{*}{$\begin{array}{r}\text { Biomass } \\
(\mu \mathrm{g} \mathrm{C})\end{array}$} \\
\hline & & & & & $\begin{array}{l}\text { High-nut } \\
\text { Mesophiles } \\
20^{\circ} \mathrm{C}\end{array}$ & $\begin{array}{l}\text { Psient agar } \\
\text { Psychrophiles } \\
2^{\circ} \mathrm{C}\end{array}$ & $\begin{array}{l}\text { Low-nutri } \\
\text { Yeast extract } \\
20^{\circ} \mathrm{C}\end{array}$ & $\begin{array}{l}\text { nt agars } \\
\text { Succinate } \\
20^{\circ} \mathrm{C}\end{array}$ & & \\
\hline 388 & $16^{\circ} 56.2^{\prime}$ & 2770 & 2.7 & $\begin{array}{l}0-2 \\
4-6\end{array}$ & $\begin{array}{l}9000 \\
6000\end{array}$ & $\begin{array}{l}14000 \\
54000\end{array}$ & $\begin{array}{l}2000 \\
1850\end{array}$ & $\begin{array}{r}1400 \\
950\end{array}$ & $\begin{array}{l}2.75 \\
2.08\end{array}$ & $\begin{array}{l}2.16 \\
1.84\end{array}$ \\
\hline 371 & $09^{\circ} 55.3^{\prime}$ & 1510 & 8.6 & $\begin{array}{l}0-2 \\
4-6\end{array}$ & $\begin{array}{l}3200 \\
4100\end{array}$ & $\begin{array}{r}20000 \\
9000\end{array}$ & $\begin{array}{l}\text { nd } \\
\text { nd }\end{array}$ & $\begin{array}{l}\text { nd } \\
\text { nd }\end{array}$ & $\begin{array}{l}\text { nd } \\
\text { nd }\end{array}$ & $\begin{array}{l}\text { nd } \\
\text { nd }\end{array}$ \\
\hline 373 & $09^{\circ} 14.3^{\prime}$ & 4670 & 2.7 & $\begin{array}{l}0-2 \\
4-6\end{array}$ & $\begin{array}{l}300 \\
300\end{array}$ & $\begin{array}{r}100 \\
70\end{array}$ & $\begin{array}{l}0 \\
0\end{array}$ & $\begin{array}{l}0 \\
0\end{array}$ & $\begin{array}{l}1.09 \\
1.19\end{array}$ & $\begin{array}{l}0.69 \\
0.77\end{array}$ \\
\hline 375 & $09^{\circ} 01.8^{\circ}$ & 4625 & 2.3 & $\begin{array}{l}0-2 \\
4-6\end{array}$ & $\begin{array}{l}430 \\
600\end{array}$ & $\begin{array}{l}200 \\
270\end{array}$ & $\begin{array}{l}100 \\
250\end{array}$ & $\begin{array}{r}0 \\
300\end{array}$ & $\begin{array}{l}1.20 \\
1.12\end{array}$ & $\begin{array}{l}0.87 \\
0.78\end{array}$ \\
\hline 376 & $09^{\circ} 08.2^{\prime}$ & 4775 & 2.3 & $\begin{array}{l}0-2 \\
4-6\end{array}$ & $\begin{array}{l}130 \\
500\end{array}$ & $\begin{array}{l}70 \\
70\end{array}$ & $\begin{array}{l}100 \\
400\end{array}$ & $\begin{array}{r}0 \\
50\end{array}$ & $\begin{array}{l}0.88 \\
0.56\end{array}$ & $\begin{array}{l}0.46 \\
0.40\end{array}$ \\
\hline 377 & $08^{\circ} 15.4^{\prime}$ & 4740 & 2.1 & $\begin{array}{l}0-2 \\
4-6\end{array}$ & $\begin{array}{l}130 \\
130\end{array}$ & $\begin{array}{r}0 \\
30\end{array}$ & $\begin{array}{l}0 \\
0\end{array}$ & $\begin{array}{r}50 \\
0\end{array}$ & $\begin{array}{l}0.88 \\
0.86\end{array}$ & $\begin{array}{l}0.66 \\
0.66\end{array}$ \\
\hline 378 & $07^{\circ} 36.6^{\prime}$ & 4622 & 2.0 & $\begin{array}{l}0-2 \\
4-6\end{array}$ & $\begin{array}{r}1200 \\
270\end{array}$ & $\begin{array}{l}700 \\
400\end{array}$ & $\begin{array}{r}450 \\
0\end{array}$ & $\begin{array}{r}50 \\
0\end{array}$ & $\begin{array}{l}1.13 \\
1.22\end{array}$ & $\begin{array}{l}0.74 \\
0.68\end{array}$ \\
\hline 381 & $05^{\circ} 37.0^{\prime}$ & 2815 & nd & $\begin{array}{l}0-2 \\
4-6\end{array}$ & $\begin{array}{l}130 \\
300\end{array}$ & $\begin{array}{l}4300 \\
2100\end{array}$ & $\begin{array}{l}0 \\
0\end{array}$ & $\begin{array}{l}0 \\
0\end{array}$ & $\begin{array}{l}1.53 \\
1.24\end{array}$ & $\begin{array}{l}1.11 \\
0.88\end{array}$ \\
\hline 383 & $02^{\circ} 59.8^{\prime}$ & 4495 & 2.3 & $\begin{array}{l}0-2 \\
4-6\end{array}$ & $\begin{array}{r}100 \\
70\end{array}$ & $\begin{array}{r}630 \\
0\end{array}$ & $\begin{array}{l}0 \\
0\end{array}$ & $\begin{array}{r}650 \\
0\end{array}$ & $\begin{array}{l}1.47 \\
0.93\end{array}$ & $\begin{array}{l}1.28 \\
0.80\end{array}$ \\
\hline 386 & $04^{\circ} 22.4^{\prime}$ & 4550 & 2.7 & $\begin{array}{l}0-2 \\
4-6\end{array}$ & $\begin{array}{r}130 \\
70\end{array}$ & $\begin{array}{r}130 \\
0\end{array}$ & $\begin{array}{l}0 \\
0\end{array}$ & $\begin{array}{l}0 \\
0\end{array}$ & $\begin{array}{l}1.20 \\
0.79\end{array}$ & $\begin{array}{l}0.76 \\
0.46\end{array}$ \\
\hline
\end{tabular}

lations of strains were done in the home laboratory. The ship returned $60 \mathrm{~d}$ after the last sampling station and, therefore, the incubation times varied between 60 and $76 \mathrm{~d}$.

The high-nutrient seawater agar (SWA) consisted of $1.5 \mathrm{~g}$ peptone, $0.3 \mathrm{~g}$ yeast extract, $0.01 \mathrm{~g} \mathrm{FePO} \cdot \mathrm{F}_{4}$. $4 \mathrm{H}_{2} \mathrm{O}, 15.0 \mathrm{~g}$ DIFCO Bacto-Agar, $750 \mathrm{ml}$ seawater and $250 \mathrm{ml}$ of distilled water (75\% seawater). The $\mathrm{pH}$ was adjusted to 7.6. The 2 low-nutrient agars were composed of $15 \mathrm{mg} \mathrm{l}^{-1}$ DIFCO yeast extract or Na-succinate and $10.0 \mathrm{~g} \mathrm{l}^{-1}$ of OXOID Agar No. 1 in $75 \%$ seawater.

For additional isolations of oligotrophic bacteria, enrichment media (5 $\mathrm{ml}$ per tube), consisting of $75 \%$ seawater with $15 \mathrm{mg} \mathrm{l}^{-1}$ glucose, glycerol, Naglutamate or Na-succinate, were inoculated in duplicate with approximately $0.1 \mathrm{ml}$ of wet sediment from the 0 to $2 \mathrm{~cm}$ layer. After an incubation period of 60 to $76 \mathrm{~d}$ at 2 or $20^{\circ} \mathrm{C}$, further subcultures were made on low-nutrient agars.

After heating subsamples of the serial dilutions for $10 \mathrm{~min}$ at $90^{\circ} \mathrm{C}$ to inactivate vegetative cells, additional spread plates on spore germination medium II (Rüger 1975) were prepared for the enumeration of bacterial spores.
Acridine Orange Direct Counts and biomass determinations. For direct count determinations, $1 \mathrm{ml}$ of sediment samples were suspended in filter-sterilized $75 \%$ seawater and homogenized with an Ultra Turrax $18 \mathrm{KG}$ blender for $1 \mathrm{~min}$ at about $20000 \mathrm{rpm}$. Cells were then preserved with formaldehyde at a final concentration of $2 \%$ and the samples stored at $4{ }^{\circ} \mathrm{C}$. Because storage could introduce perturbations in the epifluorescence counts, samples should be processed as soon as possible. However, up to 6 mo were still needed to finish direct countings. About 400 cells per filter had to be counted to achieve a statistical error of $\pm 10 \%$. Further details of the method were described previously (Tan \& Rüger 1989).

Bacteria were morphologically differentiated into 5 groups and each group counted quantitatively for biovolume determinations (Tan \& Rüger 1989). Bacterial biomasses ( $\mu \mathrm{g} \mathrm{C}$ per $\mathrm{ml}$ wet sediment) were calculated from biovolumes using the conversion factor $5.6 \times$

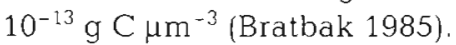

Characterization of strains. The common identification tests were performed in seawater media as described previously (Rüger 1989). The test temperatures were $4{ }^{\circ} \mathrm{C}$ for the $2{ }^{\circ} \mathrm{C}$ isolates and $20^{\circ} \mathrm{C}$ for the $20^{\circ} \mathrm{C}$ isolates. The utilization of organic substrates as sole 
sources of carbon and energy was studied in microtiter plates; turbidity was taken as an indicator for substrate utilization and measured with a microtiter plate photometer after $2,4,6$ and $8 \mathrm{wk}$ of incubation at 4 or $20^{\circ} \mathrm{C}$ (Rüger 1988). The ability to form endospores was determined microscopically after 4,8 and $12 \mathrm{wk}$ of incubation at 2 or $20^{\circ} \mathrm{C}$ in the following test media: SWA, SWA plus $15.38 \mathrm{mg} \mathrm{l}^{-1} \mathrm{MnSO}_{4} \cdot \mathrm{H}_{2} \mathrm{O}$, and in seawater broth containing the same concentrations of peptone, yeast extract and $\mathrm{FePO}_{4} \cdot 4 \mathrm{H}_{2} \mathrm{O}$ as the high-nutrient seawater agar, supplemented with $1.8 \mathrm{mM}$ (final concentration) of decoyinine, psicofuranine or psicofuranine-tetraacetate. These 3 substances were gifts from Dr R. L. Keene, Infectious Diseases Research, Upjohn Co., Kalamazoo, MI 49001, USA.

Temperature relationships were determined at 4, 12, $18,24,30$ and $37^{\circ} \mathrm{C}$ in seawater broth. Growth was measured at $650 \mathrm{~nm}$ with a Gilford photometer model 250 after 3,7 and $14 \mathrm{~d}$ of incubation.

To determine whether the strains require seawater for growth at 4 or $20^{\circ} \mathrm{C}$ within $6 \mathrm{wk}$, a distilled-water medium with the same concentrations of nutrients as the seawater broth was used.

Growth of the 2 and $20^{\circ} \mathrm{C}$ isolates under oligotrophic conditions was tested on low-nutrient agar containing $15 \mathrm{mg} \mathrm{l}^{-1}$ yeast extract and examined after 4, 8 and $12 \mathrm{wk}$ of incubation at 4 and $20^{\circ} \mathrm{C}$, respectively. The $2{ }^{\circ} \mathrm{C}$ isolates only were additionally tested $16 \mathrm{wk}$ after inoculation. The ability of the oligotrophic isolates to grow with higher concentrations of peptone and yeast extract was tested in $50 \%$ seawater supplemented with $0.1 \mathrm{mg} \mathrm{l}^{-1} \mathrm{KH}_{2} \mathrm{PO}_{4}$ and $0.3 \mathrm{mg} \mathrm{l}^{-1} \mathrm{Fe}\left(\mathrm{NH}_{4}\right)_{2}\left(\mathrm{SO}_{4}\right)_{2}$ - $6 \mathrm{H}_{2} \mathrm{O}$. The concentrations per liter of seawater broth (SWB) were:

$$
\begin{aligned}
& 5000.0 \mathrm{mg} \text { peptone }+1000.0 \mathrm{mg} \text { yeast extract: } \\
& 100 \% \mathrm{SWB}
\end{aligned}
$$

$1667.0 \mathrm{mg}$ peptone $+333.0 \mathrm{mg}$ yeast extract:

$500.0 \mathrm{mg}$ peptone $+100.0 \mathrm{mg}$ yeast extract:

$125.0 \mathrm{mg}$ peptone $+25.0 \mathrm{mg}$ yeast extract:

$$
10 \% \mathrm{SWB}
$$

$$
12.5 \mathrm{mg} \text { peptone }+2.5 \mathrm{mg} \text { yeast extract: } 2.5 \% \mathrm{SWB}
$$$$
0.25 \% \text { SWB }
$$

For each SWB-concentration a test tube containing $7 \mathrm{ml}$ of medium was inoculated with a loopful of a preculture grown on seawater agar, corresponding to $100 \%$ SWB, but solidified with $15.0 \mathrm{~g} \mathrm{l}^{-1}$ DIFCO Bacto Agar. Turbidities in the test tubes, inner diameter $15 \mathrm{~mm}$, were measured photometrically at $578 \mathrm{~nm}$ after 7,14 and $28 \mathrm{~d}$ of incubation at $2^{\circ} \mathrm{C}$ for the $2{ }^{\circ} \mathrm{C}$ isolates and $18^{\circ} \mathrm{C}$ for the $20^{\circ} \mathrm{C}$ isolates. Cultures reaching a turbidity of 0.05 or higher were considered to grow in the respective medium.

\section{RESULTS}

\section{Bacterial numbers and biomasses}

Sediment temperatures, measured immediately after recovery of the box-grab-sampler, were between 2.0 and $2.7^{\circ} \mathrm{C}$ at the site of subsampling. Exceptions were Str 371 , with $8.6^{\circ} \mathrm{C}$ in $1510 \mathrm{~m}$ depth (Table 1), and the 3 other stations at the continental slope, 368, 369 and 370, with depths of 123, 303 and $800 \mathrm{~m}$ (Fig. 1), which had sediment temperatures of $26.3,12.2$ and $6.3^{\circ} \mathrm{C}$ respectively. The latter 3 stations were considered only for colony counts in sediment samples, but excluded from community structure studies because of their shallow nature.

At depths up to $2815 \mathrm{~m}$, colony counts (CFU) after incubation at 2 and $20^{\circ} \mathrm{C}$ were definitely related to sediment temperatures. In the relatively warm sediment sampies from the 2 shallow stations 368 and 369, high quantities, 690000 and $71000 \mathrm{CFU} \mathrm{ml}^{-1}$, respectively, were found on $20^{\circ} \mathrm{C}$ plates, but only 1400 and $1200 \mathrm{CFU}$ $\mathrm{ml}^{-1}$ were estimated at $2{ }^{\circ} \mathrm{C}$. In contrast, in colder sediments from depths between 1510 and $2815 \mathrm{~m}$ (Table 1), bacteria on $2{ }^{\circ} \mathrm{C}$ plates outnumbered bacteria on $20^{\circ} \mathrm{C}$ plates by approximately 1 order of magnitude. At depths greater than about $3000 \mathrm{~m}$, quantities of CFU were generally low. Fewer colonies were detected on lownutrient than on high-nutrient agars, between 0 and $2000 \mathrm{ml}^{-1}$ on yeast extract and from 0 to $1400 \mathrm{ml}^{-1}$ on succinate agar plates. Unfortunately, the effect of incubation temperatures on colony numbers from the lownutrient agars could not be determined, because most of the $2^{\circ} \mathrm{C}$ plates were accidently frozen during transport.

The Acridine Orange Direct Counts (AODC) were on average 4 to 5 orders of magnitude higher than the numbers from colony counts (Table 1). Similar to the plate counts, highest values for AODC and biomass were found at the northernmost station, 388 at $17^{\circ} \mathrm{N}$, located in the nutrient-rich northwest African upwelling area (Fig. 1).

The numbers of bacterial spores in the sediment samples were determined on agar spread plates after inactivating the vegetative cells by heating. On plates subsequently incubated at $2{ }^{\circ} \mathrm{C}$, bacterial colonies originating from dormant spores were found only occasionally. On the other hand, the numbers of spores determined on $20^{\circ} \mathrm{C}$ plates were approximately in the same range as the heterotrophic colony counts presented in Table 1.

\section{Growth characteristics of isolates}

The same 2 and $20^{\circ} \mathrm{C}$ agar plates used for the enumeration of bacteria were taken for the isolation of approximately 1100 heterotrophic bacteria strains. 
More than $99 \%$ of the $2{ }^{\circ} \mathrm{C}$ isolates from both sediment layers grew only in seawater broth and were therefore regarded as obligately marine. On the other hand, about $70 \%$ of the $20^{\circ} \mathrm{C}$ isolates were able to grow in the medium prepared with distilled water and hence their marine nature is questionable.

All heterotrophic strains were tested for their ability to grow on low-nutrient agar containing $15 \mathrm{mg} \mathrm{l}^{-1}$ yeast extract. About $50 \%$ of the obligately marine $2{ }^{\circ} \mathrm{C}$ isolates showed visible growth within $16 \mathrm{wk}$ of incubation at $4{ }^{\circ} \mathrm{C}$, but of the $20^{\circ} \mathrm{C}$ isolates nearly $90 \%$ were able to grow in this low-nutrient medium after $12 \mathrm{wk}$ of incubation at $20^{\circ} \mathrm{C}$.

All 318 isolates from low-nutrient agars and enrichment cultures were able to grow in nutrient rich seawater broth with $5.0 \mathrm{~g} \mathrm{l}^{-1}$ peptone and $1.0 \mathrm{~g} \mathrm{l}^{-1}$ yeast extract $(100 \% \mathrm{SWB})$. However, a greater percentage of the $2{ }^{\circ} \mathrm{C}$ than of the $20^{\circ} \mathrm{C}$ isolates could grow in $2.5 \% \mathrm{SWB}$, and 14 strains or $12.7 \%$ of the $2{ }^{\circ} \mathrm{C}$ isolates grew in $0.25 \% \mathrm{SWB}$ (Table 2). Thus, the psychrophilic or psychrotrophic strains are obviously better adapted to low-nutrient deep-sea conditions than the mesophiles.

The identification tests for the heterotrophic isolates included growth experiments with 35 different organic substrates as sole sources of carbon and energy. Most of the $2{ }^{\circ} \mathrm{C}$ isolates were able to utilize amino acids and fewer strains used carbohydrates within $2 \mathrm{wk}$ of incubation at $4{ }^{\circ} \mathrm{C}$. Strains from the sediment surface were more active than strains from the 4 to $6 \mathrm{~cm}$ layer. In contrast, the majority of the $20^{\circ} \mathrm{C}$ isolates showed no growth at $4{ }^{\circ} \mathrm{C}$ in the substrate utilization media, even after prolonged incubation of up to $8 \mathrm{wk}$. More detailed studies on substrate utilization of the heterotrophic and oligotrophic isolates under conditions of different substrate concentrations and temperatures will be reported separately.

\section{Community structures}

For community structure studies only isolates from stations at $1510 \mathrm{~m}$ and deeper were selected. The number of strains which could be isolated from single deep-sea stations was often very low and test results are therefore not presented separately for each station. The strains were grouped according to latitude of sampling as shown in Tables $1 \& 3: 17^{\circ} \mathrm{N}$ (Stn 388), $10^{\circ} \mathrm{N}(\operatorname{Stn} 371), 9^{\circ} \mathrm{N}(\operatorname{Stns} 373,375,376,377,378)$, $6^{\circ} \mathrm{N}$ (Stn 381), and $4^{\circ} \mathrm{N}$ (Stns 383, 386). The total numbers of 2 and $20^{\circ} \mathrm{C}$ isolates per sediment layer and station-group are presented in Table 3.

The strains could clearly be differentiated according to their growth temperatures as shown in Fig. 2. Most of the $2{ }^{\circ} \mathrm{C}$ isolates from the sediment surface were psychrophilic or extremely psychrophilic, but psychrotrophic bacteria predominated in the deeper 4 to $6 \mathrm{~cm}$ sediment layers and also in the surface sample from the $10^{\circ} \mathrm{N}$ station (371), where the sediment temperature was higher $\left(8.6^{\circ} \mathrm{C}\right)$. In contrast, among the $20^{\circ} \mathrm{C}$ isolates from both sediment layers no psychrophiles were found; these isolates consisted of mesophilic and psychrotrophic bacteria.

The majority of the $2^{\circ} \mathrm{C}$ isolates from sediment surface samples were Gram-negative but, surprisingly, most of the cold-adapted strains from the 4 to $6 \mathrm{~cm}$ sediment layers and from the surface sample at $10^{\circ} \mathrm{N}$ belonged to the Gram-positive type, thus showing the same pattern as the $20^{\circ} \mathrm{C}$ isolates from both sediment layers (Fig. 3).

Table 2. Growth of isolates from low-nutrient agars and enrichment cultures in seawater broth (SWB) with decreasing concentrations of peptone and yeast extract within $28 \mathrm{~d}$ of incubation. Test temperatures were $2^{\circ} \mathrm{C}$ for the $2^{\circ} \mathrm{C}$ isolates (110 strains) and $18^{\circ} \mathrm{C}$ for the $20^{\circ} \mathrm{C}$ isolates (208 strains). Values are numbers of isolates showing visible growth

\begin{tabular}{|c|c|c|c|c|c|c|c|c|c|c|}
\hline \multirow[t]{2}{*}{ Stn } & \multicolumn{5}{|c|}{$2^{\circ} \mathrm{C}$ isolates } & \multicolumn{5}{|c|}{$20^{\circ} \mathrm{C}$ isolates } \\
\hline & $\begin{array}{l}\text { SWB } \\
100 \%\end{array}$ & $\begin{array}{c}\text { SWB } \\
33.3 \%\end{array}$ & $\begin{array}{l}\text { SWB } \\
10 \%\end{array}$ & $\begin{array}{l}\text { SWB } \\
2.5 \%\end{array}$ & $\begin{array}{c}\text { SWB } \\
0.25 \%\end{array}$ & $\begin{array}{l}\text { SWB } \\
100 \%\end{array}$ & $\begin{array}{c}\text { SWB } \\
33.3 \%\end{array}$ & $\begin{array}{l}\text { SWB } \\
10 \%\end{array}$ & $\begin{array}{l}\text { SWB } \\
2.5 \%\end{array}$ & $\begin{array}{c}\text { SWB } \\
0.25 \%\end{array}$ \\
\hline 373 & 6 & 5 & 5 & 5 & 0 & 13 & 13 & 13 & 5 & 0 \\
\hline 375 & 4 & 4 & 4 & 4 & 0 & 37 & 37 & 37 & 28 & 0 \\
\hline 376 & 8 & 8 & 8 & 7 & 0 & 13 & 13 & 13 & 9 & 0 \\
\hline 377 & 9 & 7 & 7 & 7 & 2 & 23 & 23 & 17 & 13 & 0 \\
\hline 378 & 14 & 14 & 14 & 14 & 7 & 31 & 31 & 31 & 25 & 0 \\
\hline 381 & 20 & 10 & 9 & 9 & 1 & 2 & 1 & 1 & 1 & 0 \\
\hline 383 & 14 & 11 & 11 & 11 & 2 & 20 & 20 & 20 & 17 & 0 \\
\hline 386 & 18 & 18 & 17 & 17 & 1 & 10 & 10 & 10 & 9 & 0 \\
\hline 388 & 17 & 6 & 6 & 4 & 1 & 59 & 59 & 54 & 33 & 0 \\
\hline \multirow[t]{2}{*}{ Total } & 110 & 83 & 81 & 78 & 14 & 208 & 207 & 196 & 140 & 0 \\
\hline & $100 \%$ & $75.5 \%$ & $73.6 \%$ & $70.9 \%$ & $12.7 \%$ & $100 \%$ & $99.5 \%$ & $94.2 \%$ & $67.3 \%$ & $0 \%$ \\
\hline
\end{tabular}


Table 3. Structure of bacterial populations in surface $(0$ to $2 \mathrm{~cm})$ and deeper $(4$ to $6 \mathrm{~cm})$ sediment layers. $2^{\circ} \mathrm{C}$ and $20^{\circ} \mathrm{C}$ isolates: strains isolated from high-nutrient seawater agar plates incubated at 2 or $20^{\circ} \mathrm{C}$; numbers in parentheses: total number of isolates

\begin{tabular}{|c|c|c|c|c|c|c|c|}
\hline \multirow{3}{*}{$\begin{array}{l}\text { Approx } \\
\text { latitude }\end{array}$} & \multirow{3}{*}{$\begin{array}{l}\text { Depth } \\
(\mathrm{m})\end{array}$} & \multirow{3}{*}{$\begin{array}{c}\text { Sediment } \\
\text { temperature } \\
\left({ }^{\circ} \mathrm{C}\right)\end{array}$} & \multirow[t]{3}{*}{ Genus } & \multicolumn{4}{|c|}{$\%$ of isolates } \\
\hline & & & & \multicolumn{2}{|c|}{$2^{\circ} \mathrm{C}$ isolates } & \multicolumn{2}{|c|}{$20^{\circ} \mathrm{C}$ isolates } \\
\hline & & & & $0-2 \mathrm{~cm}$ & $4-5 \mathrm{~cm}$ & $0-2 \mathrm{~cm}$ & $4-6 \mathrm{~cm}$ \\
\hline \multirow[t]{8}{*}{$17^{\circ} \mathrm{N}$} & 2770 & 2.7 & No. of isolates & $(35)$ & (6) & (39) & (37) \\
\hline & & & Alteromonas & 31 & 0 & 0 & 0 \\
\hline & & & Pscudomonas & 6 & 0 & 5 & 8 \\
\hline & & & Vibrio & 46 & 17 & 0 & 0 \\
\hline & & & Unident. Gram - ${ }^{d}$ & 0 & 0 & 0 & 0 \\
\hline & & & Bacillus & 17 & 83 & 85 & 84 \\
\hline & & & Gram-pos. cocci & 0 & 0 & 3 & 0 \\
\hline & & & Unident. Gram $+{ }^{b}$ & 0 & 0 & 7 & 8 \\
\hline \multirow[t]{8}{*}{$10^{\circ} \mathrm{N}$} & 1510 & 8.6 & No. of isolates & (29) & $(22)$ & (23) & (14) \\
\hline & & & Alteromonas & 31 & 0 & 0 & 0 \\
\hline & & & Pseudomonas & 0 & 0 & 0 & 0 \\
\hline & & & Vibrio & 3 & 5 & 0 & 0 \\
\hline & & & Unident. Gram - d & 0 & 0 & 0 & 0 \\
\hline & & & Bacillus & 66 & 95 & 96 & 100 \\
\hline & & & Gram-pos. cocci & 0 & 0 & 4 & 0 \\
\hline & & & Unident. Gram + ${ }^{b}$ & 0 & 0 & 0 & 0 \\
\hline \multirow[t]{8}{*}{$9^{\circ} \mathrm{N}$} & 4622 & $2.0-2.7$ & No of isolates & $(28)$ & $(17)$ & $(37)$ & (57) \\
\hline & to & & Alitelomusias & 64 & 18 & 3 & 5 \\
\hline & & & Pseudomonas & 0 & 0 & 16 & 12 \\
\hline & & & Vibrio & 18 & 12 & 0 & 0 \\
\hline & & & Unident. Gram - ${ }^{d}$ & 0 & 0 & 3 & 4 \\
\hline & & & Bacillus & 18 & 70 & 57 & 31 \\
\hline & & & Gram-pos. cocci & 0 & 0 & 13 & 44 \\
\hline & & & Unident. Gram + ${ }^{b}$ & 0 & 0 & 8 & 4 \\
\hline \multirow[t]{8}{*}{$6^{\circ} \mathrm{N}$} & 2815 & No data & No. of isolates & (55) & $(54)$ & (4) & (5) \\
\hline & & & Alteromonas & 40 & 4 & 0 & 0 \\
\hline & & & Pseudomonas & 9 & 4 & 0 & 0 \\
\hline & & & Vibrio & 16 & 11 & 0 & 0 \\
\hline & & & Unident. Gram - ${ }^{a}$ & 0 & 0 & 25 & 20 \\
\hline & & & Bacillus & 35 & 81 & 75 & 80 \\
\hline & & & Gram-pos, cocci & 0 & 0 & 0 & 0 \\
\hline & & & Unident. Gram + ${ }^{\circ}$ & 0 & 0 & 0 & 0 \\
\hline \multirow[t]{8}{*}{$4^{\circ} \mathrm{N}$} & 4495 & $2.3-2.7$ & No. of isolates & $(10)$ & (0) & (5) & $(0)$ \\
\hline & to & & Alteromonas & 60 & & 0 & \\
\hline & 4550 & & Pseudomonas & 0 & & 40 & \\
\hline & & & Vibrio & 40 & & 0 & \\
\hline & & & Unident. Gram $-{ }^{a}$ & 0 & & 0 & \\
\hline & & & Bacillus & 0 & & 20 & \\
\hline & & & Gram-pos. cocci & 0 & & 40 & \\
\hline & & & Unident. Gram + ${ }^{b}$ & 0 & & 0 & \\
\hline
\end{tabular}

The cold-adapted bacterial communities from the sediment surface as represented by the isolates from $2{ }^{\circ} \mathrm{C}$ plates were mainly composed of Alteromonas and Vibrio strains; again the shallower $\operatorname{Stn} 371$ at $10^{\circ} \mathrm{N}$ was an exception, with members of the genus Bacillus predominating (Table 3 ). This genus was also the most common among the $2{ }^{\circ} \mathrm{C}$ isolates from the 4 to $6 \mathrm{~cm}$ sediment layer and the $20^{\circ} \mathrm{C}$ isolates from both sediment layers.

\section{DISCUSSION}

\section{Bacterial numbers}

Colony forming units (CFU) of psychrophilic and mesophilic sediment bacteria proved to be dependent on the incubation and on the in situ sediment temperatures. On a previous expedition to the northwest African upwelling area with sampling stations up to 
Mesophilic $\$$ Psychrotrophic $\checkmark$ Psychrophilic $\square$ Extr. Psychr.

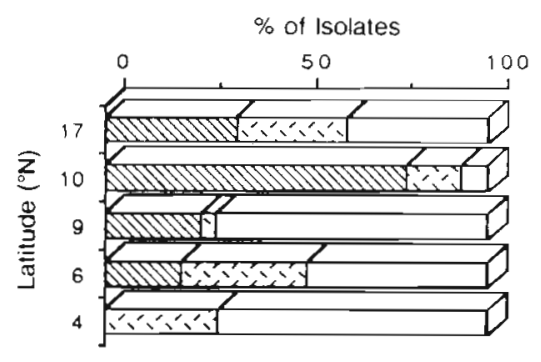

$2^{\circ} \mathrm{C}$ Isolates, Sediment layer $0-2 \mathrm{~cm}$

$20^{\circ} \mathrm{C}$ Isolates, Sediment layer $0-2 \mathrm{~cm}$

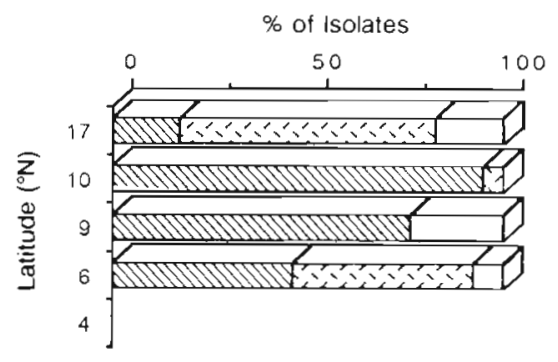

$2^{\circ} \mathrm{C}$ Isolates, Sediment layer $4-6 \mathrm{~cm}$

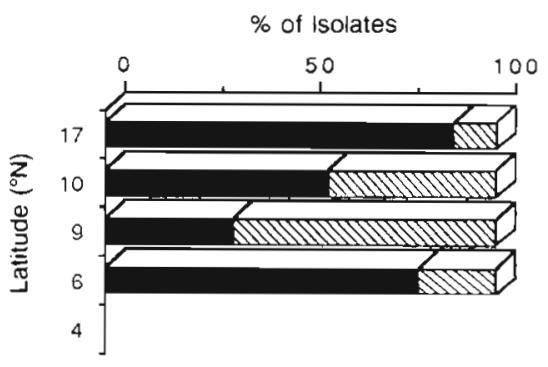

$20^{\circ} \mathrm{C}$ Isolates, Sediment layer $4-6 \mathrm{~cm}$
Fig. 2. Effect of incubation temperatures on the isolation of mesophilic, psychrotrophic, psychrophilic and extremely psychrophilic bacteria from 2 different sediment layers in the eastern tropical Atlantic. $2{ }^{\circ} \mathrm{C}$ isolates and $20^{\circ} \mathrm{C}$ isolates: strains isolated from high-nutrient seawater agar plates incubated at 2 and $20^{\circ} \mathrm{C}$, respectively; Extr. Psychr.: extremely psychrophilic

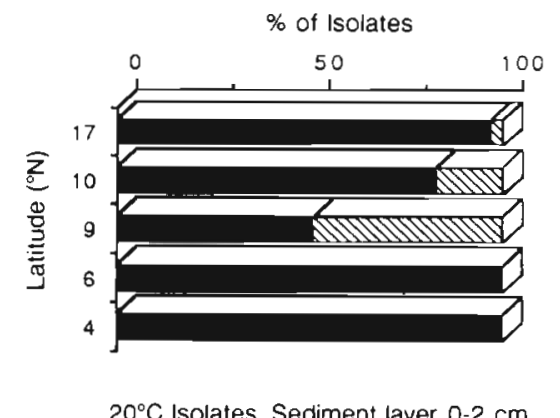

Similar results were found south of the African upwelling area during GEOTROPEX '83, but at depths greater than about $3000 \mathrm{~m}$ numbers of cultivable bacteria in the sediment were generally low (Table 1). Viable counts were in the same range as those reported by Bensoussan et al. (1979) for sediment samples from the eastern tropical Atlantic between 10 and $21^{\circ} \mathrm{N}$. Bacterial numbers from colony counts were on average 4 to 5 orders of magnitude lower than AODC, demonstrating
Gram-positive $\$$ Gram-negative

$1500 \mathrm{~m}$ water depth, the numbers of bacteria on $2^{\circ} \mathrm{C}$ plates increased with increasing depths and decreasing sediment temperatures. In samples from $1500 \mathrm{~m}$ depth, numbers of cultivable bacteria in the sediment were almost 1 order of magnitude higher for incubation at $2{ }^{\circ} \mathrm{C}$ compared to incubation at $20^{\circ} \mathrm{C}$ (Rüger 1982), indicating that low temperature adapted bacteria play an important role in degradation processes at the greater water depths in this subtropic area.
$\%$ of Isolates

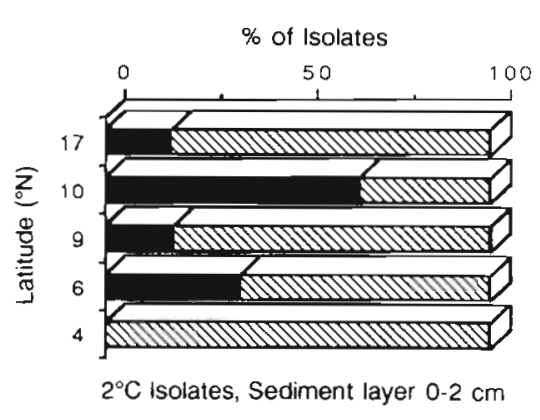

$\%$ of Isolates

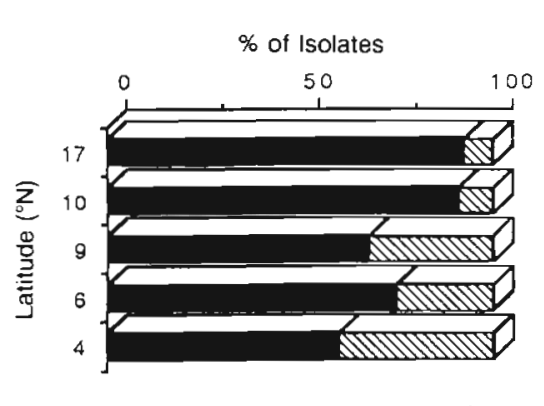

$20^{\circ} \mathrm{C}$ Isolates, Sediment layer $0-2 \mathrm{~cm}$
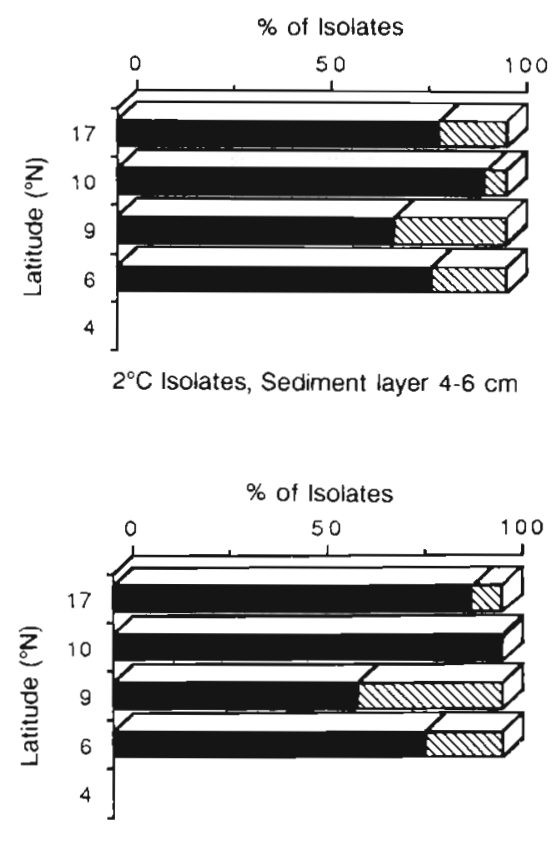

$20^{\circ} \mathrm{C}$ Isolates, Sediment layer 4-6 cm
Fig. 3. Effect of incubation temperatures on the isolation of Gram-negative and Gram-positive bacteria from 2 different sediment layers in the eastern tropical Atlantic. $2{ }^{\circ} \mathrm{C}$ isolates and $20^{\circ} \mathrm{C}$ isolates: strains isolated from high-nutrient seawater agar plates incubated at 2 and $20^{\circ} \mathrm{C}$, respectively

\footnotetext{
.
}


again that only small proportions of the bacterial communities could be cultivated on agar media (Table 1). Both numbers, CFU and AODC, were lower than at comparable depths in the nutrient rich upwelling region off northwest Africa (Tan \& Rüger 1989).

\section{Physiology and nutrition}

Although CFUs from heterotrophic agar plates incubated at 2 or $20^{\circ} \mathrm{C}$ showed only slight differences, the strains isolated from these 2 sets of plates could clearly be differentiated by their physiological characteristics. The definition of true marine bacteria is rather complex, as discussed previously (Rüger \& Hentzschel 1980). Nevertheless, the $2^{\circ} \mathrm{C}$ isolates can be regarded as indigenous marine bacteria because of their seawater requirement for growth, whereas about $70 \%$ of the $20^{\circ} \mathrm{C}$ isolates were probably of non-marine origin, as indicated by their ability to grow also in the distilled-water medium.

The obligately marine $2{ }^{\circ} \mathrm{C}$ isolates are further characterized by theil adapiation to environnental temperatures. Psychrophilic and extremely psychrophilic bacteria predominated in cold deep-sea samples, but their proportion decreased at the shallower station at $10^{\circ} \mathrm{N}$, with the higher sediment temperature of $8.6^{\circ} \mathrm{C}$ (Fig. 2). The hypothetical nonmarine origin of most of the $20^{\circ} \mathrm{C}$ isolates is supported by their mesophilic character, i.e. their failure to grow at $4{ }^{\circ} \mathrm{C}$. For technical reasons, growth temperatures of the isolates were determined at $4,12,18,24,30$ and $37^{\circ} \mathrm{C}$. Therefore, some of our psychrophilic strains may not exactly meet the generally adopted definition proposed by Morita (1975), who restricted the temperature growth range of psychrophiles from $0^{\circ} \mathrm{C}$ or lower to about $20^{\circ} \mathrm{C}$ or below. The term 'extremely psychrophilic' was applied to characterize deep-sea bacteria with exceptionally low maximum growth temperatures of between 4 and $12^{\circ} \mathrm{C}$ (Rüger 1989).

Psychrotrophic bacteria are defined as organisms growing at temperatures from $5^{\circ} \mathrm{C}$ or below to more than about $20^{\circ} \mathrm{C}$ (Baross \& Morita 1978). Psychrotrophs were isolated from $2^{\circ} \mathrm{C}$ plates from the sediment surface and, to a greater extent, from the deeper sediment layer. Organisms of this kind were also expected on the $20^{\circ} \mathrm{C}$ plates, but here the mesophiles predominated (Fig. 2).

About $50 \%$ of the $2{ }^{\circ} \mathrm{C}$ isolates but $90 \%$ of the $20^{\circ} \mathrm{C}$ isolates were able to grow on low-nutrient agar at $4{ }^{\circ} \mathrm{C}$ within $16 \mathrm{wk}$ and at $20^{\circ} \mathrm{C}$ within $12 \mathrm{wk}$, respectively. This might be explained using the report by Wiebe et al. (1992) that some psychrotrophic bacterial strains showed no marked responses to different substrate concentrations when incubated at 10 to $15^{\circ} \mathrm{C}$ or above. At lower temperatures of -1.5 and $0^{\circ} \mathrm{C}$, however, growth rates were 2 to 3 times lower in low-nutrient compared to high-nutrient media.

The reported proportions of the isolates able to grow on low-nutrient agar might be even lower, because the oligotrophic media were inoculated from high-nutrient agar cultures and organic material could have been transferred to the test tubes. Similar tests carried out with $2{ }^{\circ} \mathrm{C}$ isolates from the northwest African upwelling area revealed that 113 of 145 strains could grow after first transfer into low-nutrient medium. This is probably due to carrying over of growth material from the high-nutrient medium, because the number of isolates able to grow in low-nutrient medium decreased drastically from 113 to 26 strains after the second transfer (unpubl. data).

The concentration of $15 \mathrm{mg} \mathrm{l}^{-1}$ of organic substrates used for the isolation of oligotrophic bacteria was in the range proposed by Kuznetsov et al. (1979). Oligotrophic bacteria could be isolated from low-nutrient media, where excessive growth of copiotrophic bacteria would be retarded. However, for further cultivation of the isolates, most but not all oligotrophs will grow better on higher nutrient media (Carlucci et al. 1986).

In accordance with this all oligotrophic isolates were also able to grow in nutrient-rich seawater broth $(100 \%$ SWB), but higher proportions of the 2 than of the $20^{\circ} \mathrm{C}$ isolates could grow in the 2 most diluted SWB concentrations (Table 2). This is an indication that these psychrophilic or psychrotrophic bacteria may be better adapted to low-nutrient deep-sea conditions than the mesophiles. However, this needs further examination with the psychrophilic and psychrotrophic strains.

\section{Isolation and identification of strains}

No method of investigation is known to give complete insight into the structure and activity of microbial communities in nature. Determining bacterial numbers or cell morphologies microscopically, or following the fate of nutrients and other chemical compounds in the habitat, do not yield enough details about the microorganisms involved in the ecological processes. Analyses of natural microbial populations by ribosomal RNA sequences (Pace et al. 1986), low molecular weight RNA profiles (Höle 1990), or DNA hybridizations (Voordouw et al. 1991) require the use of standards from pre-identified bacteria and offer no information about the metabolic potential of the organisms. Consequently, isolating and cultivating the bacteria and further characterizing them in vitro is still an important method. Accordingly, the descriptions of psychrophilic deep-sea bacterial communities presented here are based on isolates from sediment samples. However, we do not know how representa 
tive of natural communities our laboratory cultures are. It is well-known that only a small fraction of the natural microflora can be isolated on agar media and that the greatest part is not cultivable at all. Thus it is still an open question whether the uncultivable part consists of unknown bacteria with special growth requirements, or of cells that become permanently or transiently uncultivable under oligotrophic conditions, and remain in the starved but viable state (Roszak \& Colwell 1987, Nilsson et al. 1991, Wiebe et al. 1992).

The number of strains isolated from each station was often too low for a comprehensive view of the bacterial communities (Bianchi \& Bianchi 1982). The grouping of similar stations according to latitude and sampling depth has been justified previously (Rüger 1989).

The isolates were identified according to Bergey's manual of systematic bacteriology $(1984,1986)$ and to numerous original publications on the taxonomy of Alteromonas, Bacillus, Pseudomonas and Vibrio. The taxonomic characteristics of most of the psychrophilic strains were not in full accordance with the descriptions given for any known species. These strains represent new taxa within the respective genera. For the characterization of the bacterial communities, the isolates are identified here only to genus level

The most reliable characteristic for differentiating between the genera Alteromonas and Pseudomonas is the guanine plus cytosine content of their DNA, but DNA base analyses are time consuming and thus not applicable in routine identification tests. The genus Alteromonas was therefore differentiated from Pseudomonas by DNase activity, $\mathrm{H}_{2} \mathrm{~S}$-production from cysteine, susceptibility to $10 \mu \mathrm{g}$ chloramphenicol and $50 \mu \mathrm{g}$ furazolidone (Oxoid sensitivity disks) and absence of nitrate reduction to gas and of a constitutive arginine dihydrolase system (Gray \& Stewart 1980). Some strains, however, did not show the complete combination of these traits and in these cases, the identification of a given strain as Alteromonas or Pseudomonas seems doubtful.

Bacillus species are characterized by their ability to form endospores. In most of the psychrophilic or psychrotrophic Gram-positive isolates from $2{ }^{\circ} \mathrm{C}$ plates, however, endospores could not be detected, but in all other characteristics these strains were identical with some endospore-producing isolates. Sporulation can be induced when the concentration of guanosine triphosphate (GTP) in the cell is lowered by substances inhibiting GTP-synthesis (Zain-ul-Abedin et al. 1983). With the use of decoyinine, psicofuranine or psicofuranine-tetraacetate, additional sporulation could not be induced and, therefore, the psychrophilic, nonsporulating, Gram-positive strains from the $2^{\circ} \mathrm{C}$ plates were considered members of the genus Bacillus that, during long periods of uniform environmental conditions in the deep-sea, have lost the ability to form endospores. This is supported by the fact that most of the cold adapted Bacillus strains must have evolved from vegetative cells, because only a few bacterial colonies were found that had developed from dormant spores on spore germination medium at $2^{\circ} \mathrm{C}$ after inactivation of the vegetative cells by heating

\section{Community structures}

Most of the obligately psychrophilic bacteria from stable cold environments like the deep-sea are considered to be Gram-negative (Baross \& Morita 1978). It was therefore an unexpected finding that the psychrotrophic, psychrophilic or even extremely psychrophilic $2{ }^{\circ} \mathrm{C}$ isolates from the deeper sediment layer were predominantly Gram-positive (Figs. 2 \& 3). Moreover, almost all of the $2{ }^{\circ} \mathrm{C}$ isolates from both sediment layers were obligately marine, but so far only a few Grampositive obligately marine bacteria have been isolated, as discussed previously (Rüger \& Hentzschel 1980, Rüger 1989). Evidently, the psychrophilic, obligately marine Bacillus strains from the deep-sea represent a group of hitherto unknown bacteria. Detailed descriptions of their physiology, nutrition and taxonomy will be published elsewhere.

The majority of the $20^{\circ} \mathrm{C}$ isolates from both sediment layers were Gram-positive and proved to be members of the genus Bacillus and of the Gram-positive cocci (Fig. 3, Table 3). Since the numbers of bacterial spores on $20^{\circ} \mathrm{C}$ plates were approximately in the same range as the heterotrophic colony counts, it is most likely that the mesophilic Bacillus strains did not originate from vegetative cells, but from dormant spores. Similar results on the composition of Gram-positive bacteria were found by Bensoussan et al. (1979) in deep-sea sediments of the same Atlantic ocean region after applying the same incubation temperature of $20^{\circ} \mathrm{C}$, which was formerly thought to allow the isolation of both psychrophilic and mesophilic bacteria. A predominance of Gram-positive sediment bacteria after incubation at room temperature, particularly cocci, was also reported for the abyssal Vema Fault, located far west of our investigated area (Bensoussan et al. 1984).

\section{CONCLUSIONS}

Besides some psychrotrophic strains, most of the $20^{\circ} \mathrm{C}$ isolates were mesophilic and, therefore, not adapted to deep-sea temperatures. Utilization of organic substrates did not occur at $4{ }^{\circ} \mathrm{C}$ and most strains were able to grow in distilled-water media. Further- 
more, the majority of strains must have evolved from dormant spores, but not from actively metabolizing cells. Considering all these facts, it is evident that the $20^{\circ} \mathrm{C}$ isolates cannot be regarded as true members of the bacterial communities in this deep-sea area. Hence, all reports about community structure studies in permanently cold environments not performed under environmental temperature conditions should be treated with care.

It can be concluded from the results that only the $2{ }^{\circ} \mathrm{C}$ isolates should be regarded as true and predominating deep-sea bacteria. They were dependent on seawater media for growth and all strains were able to grow at low temperatures (Fig. 2). Even some strains among the $2^{\circ} \mathrm{C}$ isolates, growing well at temperatures from 1 to $20^{\circ} \mathrm{C}$, utilized organic substrates preferably at $4{ }^{\circ} \mathrm{C}$ (Rüger 1988). At least the extremely psychrophilic bacteria, which already expired at temperatures between 4 and $12{ }^{\circ} \mathrm{C}$, could not have been transported with particulate organic matter from surface waters to the deep-sea, because a sediment temperature of $26.3^{\circ} \mathrm{C}$ was measured in $123 \mathrm{~m}$ depth.

Taking into account that only a small fraction of the natural microflora can be isolated on agar media, the question still remains which group of strains, the $2^{\circ} \mathrm{C}$ or the $20^{\circ} \mathrm{C}$ isolates, can be regarded as indigenous bacteria of the deep-sea communities. We can only hypothesize about the origin of obligately psychrophilic bacteria in this tropical region. Long periods of stable environmental conditions in the deep-sea may have led to the evolution of psychrophiles in the sediment. On the other hand, the Sierra Leone abyssal plain can be reached by Antarctic bottom water (Mantyla \& Reid 1983, Hollister \& McCave 1984) and psychrophilic bacteria could have been transported from the Antarctic to tropical deep-sea basins during the course of time.

Acknowledgements. We thank Christa Summa, Kirsten Fahl and Annegret Mädler for their excellent technical assistance. This research project was supported by grants from the Deutsche Forschungsgemeinschaft (Ru 204/14-1, 2, 3 and Ta 63/6-1,2).

\section{LITERATURE CITED}

Baross, J. A., Morita, R. Y (1978). Microbial life at low temperatures ecological aspects. In: Kushner, D. J. (ed.) Microbial life in extreme environments. Academic Press, London, p. 9-71

Bensoussan, M., Bianchi, A., Bianchi, M., Boudabous, A., Marty, D., Roussos, S., Lizzaraga-Partida, M.-L. (1979). Bactériologie des eaux et des sédiments profonds en Atlantique intertropical est. [ - Distribution et structure des populations bactériennes. In: Arnould, M., Pelet, R. (eds.) Geochimie organique des sédiments marins profonds, ORGON III, Mauritanie, Sénégal, lles du Cap-Vert. C.N.R.S., Paris, p. 13-25
Bensoussan, M. G., Scoditti, P.-M., Bianchi, A. J. M. (1984). Bacterial flora from echinoderm guts and associated sediment in the abyssal Vema Fault. Mar. Biol. 79: 1-10

Bergey's manual of systematic bacteriology, Vol. 1 (1984). Krieg, N. R., Holt, J. G. (eds.) Williams and Wilkins, Baltimore

Bergey's manual of systematic bacteriology, Vol. 2 (1986). Sneath, P. H. A., Mair, N. S., Sharpe, M. E., Holt, J. G. (eds.) Williams and Wilkins, Baltimore

Bianchi, M. A. G., Bianchi, A. J. M. (1982). Statistical sampling of bacterial strains and its use in bacterial diversity measurement. Microb. Ecol. 8: 61-69

Bratbak, G. (1985). Bacterial biovolume and biomass estimations. Appl. environ. Microbiol. 49: 1488-1493

Carlucci, A. F., Shimp, S. L., Craven, D. B. (1986). Growth characteristics of low-nutrient bacteria from the north-east and central Pacific Ocean. FEMS Microbiol. Ecol. 38: 1-10

Chastain, R. A., Yayanos, A. A. (1991). Ultrastructural changes in an obligately barophilic marine bacterium after decompression. Appl. environ. Microbiol. 57: 1489-1497

Deming, J. W. (1986). Ecological strategies of barophilic bacteria in the deep ocean. Microbiol. Sci. 3: 205-211

Dening, J. W., Somers, L. K., Straube, W. L., Swartz, D. G., MacDonell, M. T (1988). Isolation of an obligately barophilic bacterium and description of a new genus, Colwellia gen. nov. Syst. appl. Microbiol. 10: 152-160

Fry, J. C. (1990). Oligotrophs. In: Edwards, C. (ed.) Micro-

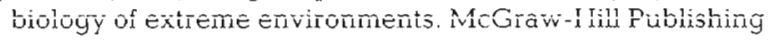
Co., New York, p. 93-116

Gray, P. A., Stewart, D. J. (1980). Numerical taxonomy of some marine pseudomonads and alteromonads. $J$ appl. Bact. 49: 375-383

Hauxhurst, J. D., Krichevsky, M. I., Atlas, R. M. (1980). Numerical taxonomy of bacteria from the Gulf of Alaska. J. gen. Microbiol. 120: 131-148

Höfle, M. G. (1990). RNA chemotaxonomy of bacterial isolates and natural microbial communities. In: Overbeck, J., Chrost, R. (eds.) Aquatic microbial ecology - biochemical and molecular approaches. Springer-Verlag, New York, p. $129-158$

Hollister, C. D., McCave, I. N. (1984). Sedimentation under deep-sea storms. Nature, Lond. 309: 220-225

Jaenicke, R. (1988). Molekulare Mechanismen der Adaptation von Bakterien an extreme Bedingungen. Forum Mikrobiologie 11. 435-440

Jannasch, H. W., Wirsen, C. O. (1984). Variability of pressure adaptation in deep sea bacteria. Arch. Microbiol. 139: $281-288$

Kaneko, T., Krichevsky, M. I., Atlas, R. M. (1979). Numerical taxonomy of bacteria from the Beaufort Sea. J. gen Microbiol. 110: 111-125

Kuznetsov, S. I., Dubinina, G. A., Lapteva, N. A. (1979) Biology of oligotrophic bacteria. Ann. Rev. Microbiol. 33 $377-387$

Mantyla, A. W., Reid, J. L. (1983). Abyssal characteristics of the World Ocean waters. Deep Sea Res. 30: 805-833

Morita, R. Y. (1975). Psychrophilic bacteria. Bacteriol. Rev. 39 $144-167$

Namsaraev, B. B. (1985). Distribution of cellulose-decomposing microorganisms in bottom sediments of the Indian Ocean. Microbiology 53: 801-807 (Translated from Mikrobiologiya 53: 982-988, 1984)

Nilsson, L., Oliver, J. D., Kjelleberg, S. (1991). Resuscitation of Vibrio vulnificus from the viable but nonculturable state. J. Bacteriol. 173: 5054-5059

Norkrans, B., Stehn, B. O. (1978). Sediment bacteria in the deep Norwegian Sea. Mar. Biol. 47: 201-209 
Pace, N. R., Stahl, D. A., Lane, D. J., Olsen, G. J. (1986). The analysis of natural microbial populations by ribosomal RNA sequences. In: Marshall, K. C. (ed.) Advances in microbial ecology, Vol. 9. Plenum Press, New York, p. $1-55$

Roszak, D. B., Colwell, R. R. (1987). Survival strategies of bacteria in the natural environment. Microbiol. Rev. 51: $365-379$

Rüger, H.-J (1975). Bakteriensporen in marinen Sedimenten (Nordatlantik, Skagerrak, Biskaya und Auftriebsgebiet vor Nordwestafrika) - quantitative Untersuchungen. Veröff. Inst. Meeresforsch. Bremerh. 15: 227-236

Rüger, H.-J. (1982). Psychrophilic sediment bacteria in the upwelling area off NW-Africa. Naturwissenschaften 69: $448-450$

Rüger, H.-J. (1984). Temperature effects on respiratory electron transport system (ETS) in psychrophilic and mesophilic marine bacteria. Veröff. Inst. Meeresforsch. Bremerh. 20: 29-40

Rüger, H.-J. (1986). Distribution, growth temperatures, and Gram reactions of psychrophilic sediment bacteria from tropical and subtropical regions off West-Africa. Deuxième Colloque International de Bactériologie marine - CNRS, Brest, 1-5 octobre 1984. IFREMER, Actes de Colloques 3: 97-101

Rüger, H.-J. (1988). Substrate-dependent cold adaptations in some deep-sea sediment bacteria. Syst. appl. Microbiol. 11: $90-93$

Rüger, H.-J. (1989). Benthic studies of the northwest African upwelling region: psychrophilic and psychrotrophic bacterial communities from areas with different upwelling intensities. Mar. Ecol. Prog. Ser. 57: 45-52

Rüger, H.-J., Hentzschel, G. (1980). Mineral salt requirements of Bacillus globisporus subsp. marinus. Arch. Microbiol. 126: $83-86$

Tabor, P. S., Ohwada, K., Colwell, R. R. (1981). Filterable

This article was submitted to the editor marine bacteria found in the deep-sea: distribution, taxonomy, and response to starvation. Microb. Ecol. 7 $67-83$

Tabor, P. S., Deming, J. W., Ohwada, K., Colwell, R. R. (1982). Activity and growth of microbial populations in pres. surized deep-sea sediment and animal gut samples. Appl. environ. Microbiol. 44: 413-422

Tan, T L., Rüger, H.-J. (1989). Benthic studies of the Northwest African upwelling region: bacteria standing stock and ETS-activity, ATP-biomass and Adenylate Energy Charge. Mar. Ecol. Prog. Ser. 51: 167-176

Tanner, A. C., Herbert, R. A. (1982). A numerical taxonomic study of gram-negative bacteria from the Antarctic marine environment. In: Deuxième Colloque de Microbiologie Marine, Marseille, 24-25 juin 1981. Publ. CNEXO (Actes Colloq.) no. 13, p. $31-38$

Voordouw, G., Voordouw, J. K., Karkhoff-Schweizer, R. R., Fedorak, P. M., Westlake, D. W. S. (1991). Reverse sample genome probing, a new technique for identification of bacteria in environmental samples by DNA hybridization, and its application to the identification of sulfate-reducing bacteria in oil field samples. Appl. environ. Microbiol. 57: $3070-3078$

Wiebe, W. J., Sheldon Jr, W. M., Pomeroy, L. R. (1992). Bacterial growth in the cold: evidence for an enhanced substrate requirement. Appl. environ. Microbiol. 58: 359-364

Yayanos, A. A. (1986). Evolutional and ecological implications of the properties of deep-sea barophilic bacteria. Proc. natn. Acad. Sci. USA 83: 9542-9546

Yayanos, A. A., Dietz, A. S. (1982). Thermal inactivation of a deep-sea barophilic bacterium, isolate CNPT-3. Appl. environ. Microbiol. 43: 1481-1489

Zain-ul-Abedin, Lopez, J M., Freese, E. (1983). Induction of bacterial differentiation by adenine- and adenosineanalogs and inhibitors of nucleic acid synthesis. Nucleosides and Nucleotides 2: 257-274

Manuscript first received: March 26, 1992

Revised version accepted: May 25, 1992 